\title{
A new species of Solanum (Solanaceae) from the mid north coast of New South Wales
}

\author{
A.R. Bean \\ Queensland Herbarium, Brisbane Botanic Gardens, Mt Coot-tha Road, Toowong 4066 \\ Queensland
}

\begin{abstract}
Solanum sulphureum A.R.Bean sp. nov. is described and illustrated. It is related to S. brownii and other species in the informal S. macoorai group, and is apparently confined to lowland rainforest in the Taree district on the mid north coast of New South Wales. Its conservation status and relationships are discussed.
\end{abstract}

\section{Introduction}

While examining a loan of Solanum specimens from the National Herbarium of New South Wales, I was puzzled by an unidentified specimen collected in 1983 from Killibakh Creek near Taree. At first I took it to be an introduced species, but later concluded that it was native, in view of the many character states shared with the indigenous Solanum brownii and its allies. Subsequent field studies have confirmed its native status.

The new species belongs in the Solanum brownii group, which is in turn a part of the informal S. macoorai group, i.e. Group 27B of Bean (2004). The S. brownii group now excludes $S$. cinereum. $S$. cinereum has previously been considered closely related to S. brownii (Symon 1981, Bean 2001) and was placed in the S. macoorai group by Bean (2004), but I now recognise that $S$. cinereum fits much more readily into the informal S. hystrix group (Group 25 of Bean 2004).

Nomenclature in relation to the indumentum follows Bean (2004).

\section{Taxonomy}

Solanum sulphureum A.R.Bean, sp. nov.

Solano brownii affinis sed foliis ovatis basi obtusis vel cordatis, pilis stellatis majoribus in partibus vegetativis, antheris brevioribus, ovario pilis stellatis carente et seminibus parvis differens.

Type: New South Wales: North Coast: $4.3 \mathrm{~km}$ along Somerset road, WSW of Wingham, A.R. Bean 23356, 29 December 2004 (holo BRI; iso NSW, MEL). 
Erect, rhizomatous perennial shrub 0.9-2.5 m high. Adult branchlets yellow, rusty or brown; prickles 2-15 per decimetre, straight, acicular, 5-11 mm long, 8-14 times longer than wide, glabrous; stellate hairs dense or very dense, $0.6-1 \mathrm{~mm}$ diameter, stalks $0.2-1.2 \mathrm{~mm}$ long; lateral rays 7 or 8 , porrect or ascending, central ray $0.7-$ 1 times as long as laterals, not gland-tipped; type 2 hairs dense. Juvenile leaves 9-12 cm long, 6-8.5 cm wide, with 2 or 3 pairs of lateral lobes, apex acute, base obtuse to cordate; prickles present on midvein and lateral veins. Adult leaves ovate, entire, lamina 6.5-12.3 cm long, 2.3-5.8 cm wide, 2.1-2.8 times longer than broad, apex acute, base obtuse or cordate, oblique part 0-4 mm long, obliqueness index 0-5 percent; petioles 0.8-3.1 cm long, 12-27 \% length of lamina, prickles absent or present. Upper leaf surface green, prickles absent or present on midvein only, or occasionally on lateral veins also, prickles $0-7$, straight, acicular, 8-12 mm long; stellate hairs distributed throughout, protostellae present, density sparse to moderate. Upper leaf surface ordinary stellae $0.2-0.6 \mathrm{~mm}$ apart, $0.4-0.7 \mathrm{~mm}$ across, stalks $0.1-0.8 \mathrm{~mm}$ long, lateral rays $4-8$, porrect or ascending, central ray $0.8-1.5$ times as long as laterals, central ray not gland-tipped; simple hairs absent; type 2 hairs present throughout, $0.05-0.1 \mathrm{~mm}$ apart. Lower leaf surface greenish white, white or grey; prickles absent or present on midvein only, $0-3$, straight, acicular; stellate hairs dense or very dense; stellae $0.1-0.25 \mathrm{~mm}$ apart, $0.6-1.2 \mathrm{~mm}$ diameter, stalks $0.2-1.2 \mathrm{~mm}$ long; lateral rays 7 or 8 , rays porrect; central ray $0.7-1.3$ times as long as laterals, not gland-tipped; simple hairs absent; type 2 hairs present throughout, $0.05-0.2 \mathrm{~mm}$ apart. Inflorescence supra-axillary, cymose (pseudo-racemose), common peduncle absent or present, 0-7 $\mathrm{mm}$ long, rachis prickles absent or present, 7-11-flowered, with some bisexual and some male flowers. Flowers 5-merous; pedicels at anthesis 10-13 mm long, same thickness throughout, prickles absent or present. Calyx tube at anthesis 3-4 mm long; calyx lobes at anthesis deltate, 2.5-4 mm long; calyx prickles at anthesis absent or present, $0-5$ per flower; stellate hairs very dense, yellow or brown or rusty, $0.6-0.7 \mathrm{~mm}$ across, stalks $0.1-0.5 \mathrm{~mm}$ long, lateral rays 7 or 8 , central ray $0.8-1.2$ times as long as laterals, not gland-tipped; simple hairs absent. Corolla purple, c. $14 \mathrm{~mm}$ long, shallowly lobed, inner surface glabrous. Anthers 4.0-4.3 mm long. Ovary with type 2 hairs only; functional style c. $8 \mathrm{~mm}$ long, protruding between anthers, with type 2 hairs only. Fruiting calyx lobes less than half length of mature fruit; prickles absent or present, 2-7 mm long. Mature fruits 1-4 per inflorescence, globular, 14-19 mm diameter, yellow or yellowish green, 1-locular (septum absent or incomplete); placenta stalked, anvil-shaped; mesocarp juicy, succulent; exocarp 0.7-1.1 mm thick; pedicels at fruiting stage 19-22 mm long, 1.1-1.5 mm thick at mid-point. Seeds pale yellow, 2.2-2.5 mm long. (Fig. 1).

Specimens examined: New South Wales. Port Macquarie, collector unknown, Oct 1892 (NSW); Killibakh Ck via Wingham, T. Launders 16, Oct 1983 (BRI, NSW); Woodside, Manning River, Cameron s.n., Oct 1911 (NSW); 3.4 km along Mulligans Lane, near Burrell Creek, WSW of Taree, A.R. Bean 23376, Dec 2004 (BRI, MO, NSW).

Derivation of name: from the Latin sulphureus - sulphur yellow, in reference to the colour of the mature fruits.

Distribution: known from the Taree-Wingham area on the mid north coast of New South Wales. The 1892 specimen cited above gives the location merely as 'Port Macquarie', but the collection was probably made many kilometres from the town, as no suitable habitats are apparent close to Port Macquarie. 


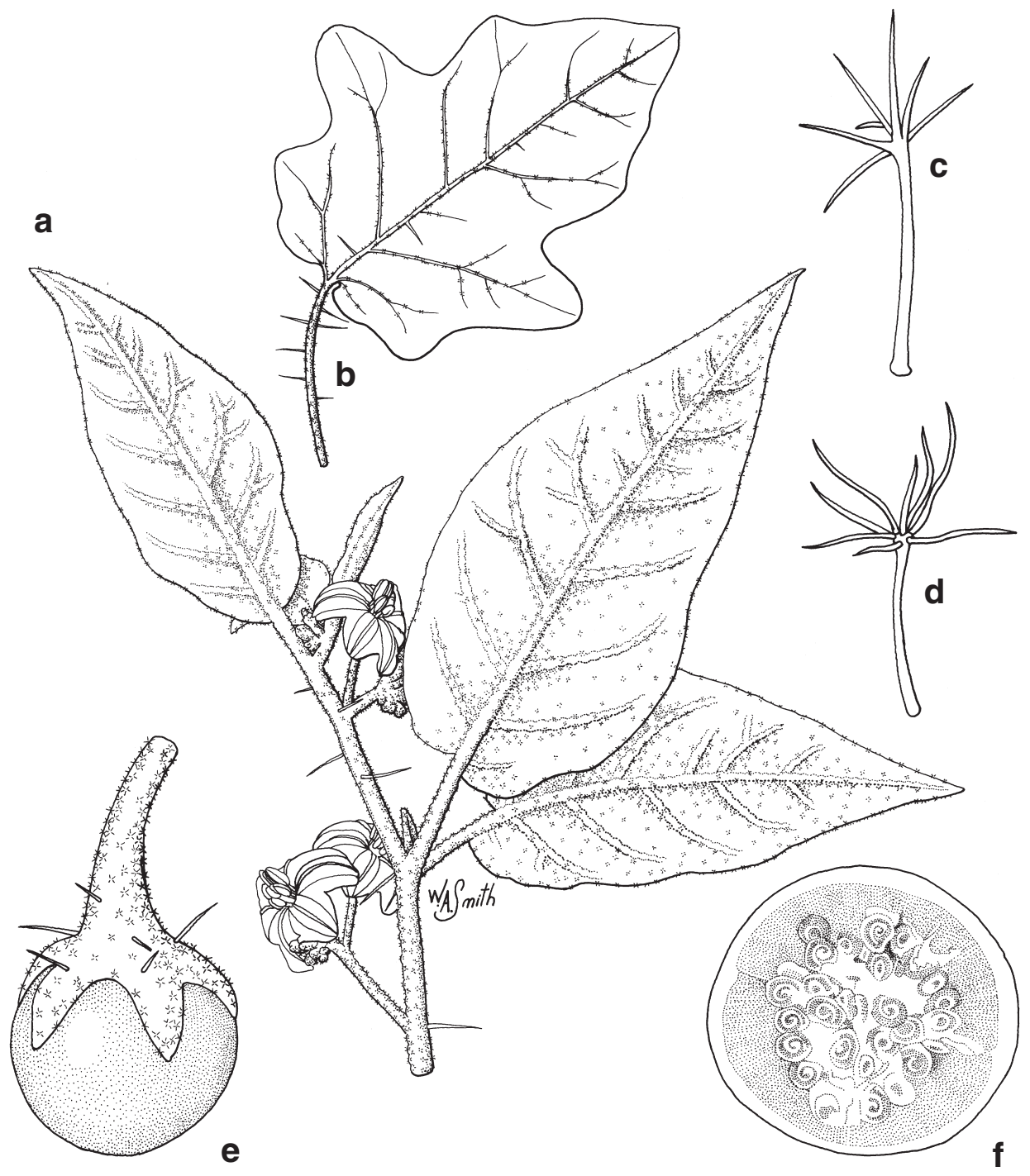

Fig. 1. Solanum sulphureum. a, flowering branchlet $\times 0.8$; b, juvenile leaf $\times 0.6$; $\mathbf{c}$, a stellate hair from the upper leaf surface $\times 40$; $\mathbf{d}$, a stellate hair from the lower leaf surface $\times 40$; e, a mature fruit with attached calyx $\times 1.5$; f, transverse section of fruit $\times 2$ (a, c, d from Bean 23356; b, e, f from Bean 23376). 
Habitat: it inhabits sunny breaks in rainforest, rainforest regrowth on pasture land, or eucalypt forest with rainforest understorey. The soils are loams or clay-loams, shallow or deep. All collections have been from low altitudes ( $<200$ metres).

Conservation status: for the populations where the land use is cattle grazing, S. sulphureum is threatened by competition from aggressive pasture grasses, inevitably leading to a decline in population for the Solanum. My encounters with some local graziers indicated that they perceive any prickly plant to be a noxious weed, and that all 'native tomatoes' are poisonous and will result in the death of cattle. Hence the species is threatened by active destruction by humans. It not known from any Nature reserves or State Forests. A conservation status of Vulnerable (VU B2ab(iii,v); C1) is recommended, based on the Red List criteria (IUCN 2001).

Affinities: S. sulphureum is distinguishable from other Australian species by the entire ovate adult leaves $(2.1-2.8 \mathrm{~cm}$ times longer than wide), the dense to very dense stellate hairs with stalks up to $1.2 \mathrm{~mm}$ long, the few-flowered cymose inflorescence, the calyx with few or no prickles and with stellate hairs $0.6-0.7 \mathrm{~mm}$ diameter, and the globose yellow fruits 14-19 mm diameter.

S. sulphureum is related to $S$. brownii, but differs by the adult leaves $2.3-5.8 \mathrm{~cm}$ broad with obtuse or cordate bases $(1.4-2.9 \mathrm{~cm}$ broad, base cuneate or attenuate for S. brownii), the much larger stellate hairs on all vegetative parts of the plant, the presence of type 2 hairs on the branchlets and leaves, the anthers $4-4.3 \mathrm{~mm}$ long (5-6 mm for S. brownii), the yellow fruits (green or yellowish-green for S. brownii), and the seeds 2.2-2.5 mm long (2.6-3.1 mm long for S. brownii).

\section{Acknowledgments}

I am grateful to the Director of the National Herbarium of New South Wales for the loan of specimens. Will Smith (BRI) prepared the illustration, and Peter Bostock provided the Latin diagnosis.

\section{References}

Bean AR (2001) A revision of Solanum brownii Dunal (Solanaceae) and its allies. Telopea 9: $639-61$.

Bean AR (2004) The taxonomy and ecology of Solanum subg. Leptostemonum (Dunal) Bitter

(Solanaceae) in Queensland and far north-eastern New South Wales, Australia. Austrobaileya 6(4): 639-816.

IUCN (2001) IUCN Red List Categories and Criteria: Version 3.1. (IUCN Species Survival Commission, IUCN: Gland, Switzerland and Cambridge, UK)

Symon DE (1981) A revision of the genus Solanum in Australia. Journal of the Adelaide Botanic Gardens 4: 1-367. 